\title{
Heavy Metals in Soft Tissues of Short-Beaked Common Dolphins (Delphinus delphis) Stranded along the Algerian West Coast
}

\author{
Larbi Doukara Kamel ${ }^{1}$, Bouslah Yahia², Bouderbala Mohammed ${ }^{2}$, Boutiba Zitouni2 \\ ${ }^{1}$ Faculty of the Sciences of the Nature and Life, University of Blida, Blida, Algeria \\ ${ }^{2}$ The Environmental Surveillance Network Laboratory, University of Oran, Oran, Algeria \\ Email: ${ }^{\text {artimaquakamel@yahoo.fr }}$
}

Received 24 November 2013; revised 13 December 2013; accepted 9 January 2014

Copyright (C) 2014 by authors and Scientific Research Publishing Inc.

This work is licensed under the Creative Commons Attribution International License (CC BY). http://creativecommons.org/licenses/by/4.0/

(c) (i) Open Access

\begin{abstract}
Liver, muscle and blubber tissues of seven Common dolphins (Delphinus delphis) stranded along the Algerian west coast have been analysed for six traces elements $\mathrm{Cu}, \mathrm{Fe}, \mathrm{Cd}, \mathrm{Pb}, \mathrm{Zn}$ and $\mathrm{Ni}$. This work confirms more accurately the relations shown previously between age, sex and trace element concentrations in this species. Liver was shown to be the most important accumulating organ for $\mathrm{Cu}, \mathrm{Fe}$ and $\mathrm{Zn}$, and the results also indicated the importance of toxic metal transfer from mother to offspring. Significant differences between the liver, muscle and blubber were detected; except for the Ni concentrations were similar in these tissues.
\end{abstract}

Keywords

Delphinus delphis; Traces Elements; Algerian West Coast; Liver; Muscle; Blubber

\section{Introduction}

The levels of trace metals can be affected by human industrial and mining activity, as well as agricultural and domestic wastes, the combustion of fossil fuels and also by natural factors such as erosion and volcanic and tectonic activities.

These elements are widely dispersed in the marine mammals through several different routes: atmospheric uptake via the lungs, absorption through the skin, across the placenta before birth, via milk through lactation, and ingestion of sea water.

Cetaceans are generally considered integrators of environmental pollutants such as metals due to their longevity

*Corresponding author.

How to cite this paper: Kamel, L.D., et al. (2014) Heavy Metals in Soft Tissues of Short-Beaked Common Dolphins (Delphinus delphis) Stranded along the Algerian West Coast. Open Journal of Marine Science, 4, 110-117.

http://dx.doi.org/10.4236/ojms.2014.42012 
and their elevated position in marine foods webs [1].

Nevertheless, most marine organisms concentrate trace elements at higher concentrations than those occurring in their environment.

The study of heavy metals accumulation is important because of the toxic effects that these pollutants can cause, especially in organisms at the top of marine food chain.

Cetaceans accumulate heavy metals which enter the food web naturally, or as a result of marine pollution, accumulation may be correlated with age and sex, and depends on food sources, the physiological state of the individual and the toxicological dynamics of the specific metal, consequently, a high variability in trace metal concentration exists among cetacean species and marine habitats [2]-[6].

Hence, the marine mammals appear to be potentially valuable indicator of the level of heavy metals accumulated in the marine environment: according to their top position in the trophic network, their long life span and their long biological half-time of elimination of pollutants [7]-[10].

In this paper, the concentrations of metals (cadmium, Cd; lead, Pb; zinc, Zn; copper, $\mathrm{Cu}$; iron, Fe; Ni, Nickel) in tissues and organs of seven specimens of Delphinus delphinus (four males and two females, one mothers gestated with foetus male) are presented.

Metals levels have also compared with those found in dolphins from other geographical areas, in order to show a possible relationship between the accumulation and the contamination of the marine environment.

\section{Material and Methods}

\subsection{Studied Areas}

The Algerian west coast where the dead cetaceans were found includes Ain Temouchent coast, Oran coast and Mostaganem coast (Figure 1).

These coastal areas suffer from high levels of urban andindustrial pollution, since they are continually exposed to discharges of untreated wastewater and consequently to contamination by heavy metals, polyaromatic hydrocarbons and organochlorine compounds [11]-[13].

\subsection{Biological Material}

Between 2008 and 2011, 40 stranded small cetaceans were sampled along the Algerian west coast by the

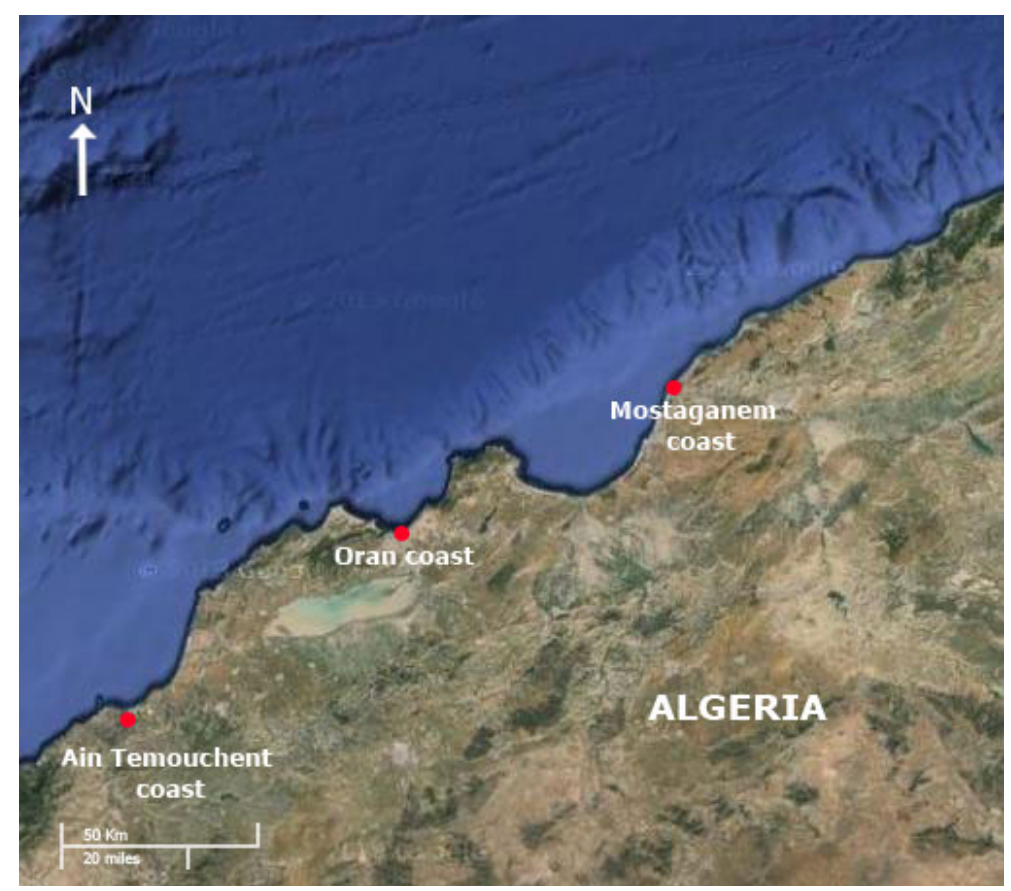

Figure 1. Map showing Algerian west coast. 
network of Cetacean stranding coordinated by the Environmental Surveillance Network Laboratory of the University of Oran (LRSE).

Delphinus delphis, the most common species $(\mathrm{n}=7)$ were collected based on the degree of postmortem autolysis, all carcasses had moderate signs of decomposition, following the recommendations of Jauniaux et al. (2002) [14]. No animals exhibiting advanced stages of decomposition (e.g. tissue autolysis) were included in the presented analyses.

The samples were collected post-mortem from 07 Delphinus delphis (four males and two females, one pregnant female with foetus male), shows the coastal area where the dead cetaceans were found in Figure 1.

These animals are classified into categories (03) based on the works of Boutiba (1992) [15]; It was observed that fore dolphins were sexually mature (two males and two females): their length ranged from 175 to $197 \mathrm{~cm}$, and two males specimens was a sexually immature (length 105and $119 \mathrm{~cm}$ ), and one foetus male (length 81, 5 $\mathrm{cm}$ ), the foetus from this study would have been collected at early to mid-pregnancy periods (Table 1).

Each animal was carefully identified with a number and measured, and sex was determined according to Norris (1961) [16].

The nutritional condition of these animals, established from visual assessment of dorsal muscles and blubber thickness, was good in most cases. No individuals could be classified as showing a poor nutritional condition, all carcasses were fresh (intact pigmentation, cloudy eyes, tern coloration of organs during dissection), some external observations have permitted to classify all these individuals as accidentally by- caught.

In addition, the blubber, muscle and liver of these invidious were systematically sampled and stored in plastic bags at $-20^{\circ} \mathrm{C}$ for trace elements analyses.

\subsection{Metal Analyses}

The concentration of Heavy metals essential (zinc ( $\mathrm{Zn})$, copper (Cu), iron (Fe),), and non-essential metals (lead $(\mathrm{Pb})$, cadmium $(\mathrm{Cd})$ ) and other potential toxic elements, such as Nickel (Ni), were measured in whole soft tissues of Delphinus delphis after hot mineralization samples, following the method of Amiard et al. (1987) [17].

Approximately $1 \mathrm{~g}$ of wet weight (w. wt.) was digested in $4 \mathrm{ml}$ of concentrated nitric acid (Merck Suprapure) at $95^{\circ} \mathrm{C}$ for 1 hour. The metal contents in acid solutions were determined by using a flame atomic absorption spectrophotometer equipped with a graphite furnace (Perkin Elmer AAnalyst-100-Version 1.10).

Detection limits were determined with blank analyses, and the quality controls were made using standard reference materials (Mussel Tissue Standard Reference Material (SRM 2976), National Institute of Standards and Technology). These standards were treated and analysed under the same conditions as the samples and results were in good agreement with the certified values.

Concentrations obtained for standard reference materials were always within the $95 \%$ confidence interval of certified values (Table 2).

\subsection{Statistical Analysis}

The data are presented as the mean \pm standard error of the mean. One-way analyses of variance (ANOVA) were used to compare means of heavy metal concentrations between tissues. When ANOVA was significant ( $\mathrm{p}$

Table 1. Biological data of Delphinus delphis sampled between 2008 and 2011 along the Algerian west coast.

\begin{tabular}{ccccc}
\hline Gender & Maturity & Body length $(\mathrm{cm})$ & Year of finding & Location of finding \\
Female $\left(\mathrm{N}^{\circ}\right.$ 01) & Mature & 186 & $07 / 06 / 2008$ & Oran \\
Male $\left(\mathrm{N}^{\circ}\right.$ 02) & Immature & 119 & $10 / 05 / 2011$ & Mersa el Hadjaj \\
Male $\left(\mathrm{N}^{\circ}\right.$ 03) & Immature & 105 & $29 / 10 / 2011$ & Ain Témouchent \\
foetus male $\left(\mathrm{N}^{\circ} 04\right)$ & foetus & 81.5 & $21 / 03 / 2011$ & Mersa el Hadjaj \\
Pregnantfemale $\left(\mathrm{N}^{\circ}\right.$ 05) & Mature & 175 & $21 / 03 / 2011$ & Mersa el Hadjaj \\
Male $\left(\mathrm{N}^{\circ}\right.$ 06) & Mature & 194 & $14 / 04 / 2011$ & Ain Témouchent \\
Male $\left(\mathrm{N}^{\circ}\right.$ 07) & Mature & 197 & $10 / 08 / 2011$ & Mersa el Hadjaj \\
\hline
\end{tabular}


Table 2. Observed and certified values of heavy metal concentrations ( $\mu \mathrm{g} / \mathrm{g}$ dry wt.) in the standard reference material (SRM 2976).

\begin{tabular}{ccccccc}
\hline & $\mathrm{Cu}$ & $\mathrm{Fe}$ & $\mathrm{Cd}$ & $\mathrm{Pb}$ & $\mathrm{Zn}$ & $\mathrm{Ni}$ \\
\hline Measured value & $3.96 \pm 0.08$ & $169 \pm 4.6$ & $0.78 \pm 0.03$ & $1.15 \pm 0.04$ & $128 \pm 8.00$ & $0.91 \pm 0.11$ \\
Certified value & $4.02 \pm 0.33$ & $171 \pm 4.9$ & $0.82 \pm 0.16$ & $1.19 \pm 0.18$ & $137 \pm 13.00$ & $0.93 \pm 0.12$ \\
\hline
\end{tabular}

0.05), post-hoc comparison of means was done using the Newman-Keuls test. Statistical analysis was performed using the software STATISTICA (Statsoft STATISTICA version 6.1.478.0).

\section{Results}

In this works we will focus on heavy metals and their possible effects on marine mammals.

Heavy metals are usually divided into essential ( $\mathrm{Zn}, \mathrm{Cu}, \mathrm{Ni}, \mathrm{Fe}$ ) and non-essential metals (Cd, $\mathrm{Pb}$ ).

The mean, range and standard error (SE) of the studied elements for the analyses wet weight liver, blubber and muscle of the species, the (SE) is based on a number of samples corresponding to three (03) replicates of each one.

Summarized descriptive statistics of $\mathrm{Cu}, \mathrm{Fe}, \mathrm{Cd}, \mathrm{Pb}, \mathrm{Zn}$ and $\mathrm{Ni}$ concentration in muscle, blubber and liver tissues of Common dolphins (Delphinus delphis) were listed in Table 3.

Among these tissues, liver is the most important accumulating organ for the metals to choose.

$\mathrm{Cu}, \mathrm{Fe}$ and $\mathrm{Zn}$ were significantly lowest in blubber and muscle and significantly higher in liver, but no significant difference was recorded for $\mathrm{Ni}(\mathrm{p}<0.05)$ which the concentrations ranged from 43.40 to $55.38 \mu \mathrm{g} / \mathrm{g}$.

However, the traces elements not essential, there concentration are ranged from 0.21 to $0.39 \mu \mathrm{g} / \mathrm{g}$ for $\mathrm{Cd}$ and 0.21 to $6.62 \mu \mathrm{g} / \mathrm{g}$ for $\mathrm{Pb}$, no sex-related difference in $\mathrm{Pb}$ and $\mathrm{Cd}$ concentrations was observed ( $<<0.05)$.

In general, the concentration of $\mathrm{Cu}$ in all organs increased with sex and maturity $(\mathrm{p}<0.05)$, however $\mathrm{Zn}$, $\mathrm{Pb}$, Ni were independent of maturity.

In the pregnant female, the concentration of $\mathrm{Cu}$ is significantly higher $(39.63 \mu \mathrm{g} / \mathrm{g})$ by contribution the other cloths, Fe are present at higher in the muscle $(140.45 \mu \mathrm{g} / \mathrm{g})$, pregnant females exhibited significantly higher (p < 0.05) Fe muscle concentrations compared to those in foetus.

However, the concentration of Cd is ranged from 0.21 to $0.45 \mu \mathrm{g} / \mathrm{g}$, is present slightly higher; In liver the other tissues, Cd concentration were usually lower than $0.39 \mu \mathrm{g} / \mathrm{g}$, except in specie $\left(\mathrm{N}^{\circ}: 02\right)$ is slightly higher in blubber $(0.32 \mu \mathrm{g} / \mathrm{g})$ in relation to the $0.30 \mu \mathrm{g} / \mathrm{g}$ in liver.

There were significant differences in specie $\left(\mathrm{N}^{\circ}: 03\right)$ one notice that the concentration of the $\mathrm{Pb}$ is higher by reports the other with the mean concentrations which did not exceed $6.62 \mu \mathrm{g} / \mathrm{g}$ in blubber, and is continuated by the species $\left(\mathrm{N}^{\circ}: 01 ; 02\right)$ with a maximum in the liver of specie $\left(\mathrm{N}^{\circ}: 01\right)$.

\section{Discussion}

Due to the rarity of the references in Algeria, it is difficult to compare the results obtained in this study, but can be critically evaluated with those levels recorded by Shoham-Frider et al. (2009) [18], in the Levantine basin of the eastern Mediterranean; Lahaye et al. (2007) [19], in French coasts and Carvalho et al. (2002) [20], in West Atlantic.

In our study $\mathrm{Cu}, \mathrm{Fe}, \mathrm{Cd}, \mathrm{Zn}$ concentration measured were generally lower than those reported elsewhere for blubber, muscle and liver tissues of Mediterranean dolphins, with exception of the Nickel (Ni)and lead (Pb).

In addition, significantly higher $(\mathrm{p}<0.05)$ the essential metals concentration were found in liver.

Furthermore, concentration of $\mathrm{Cu}, \mathrm{Fe}, \mathrm{Cd}, \mathrm{Zn}$ are close to or below the detection limited in the liver and muscle of all specimens, the liver was shown to be the most important accumulating organ for this metals, due to its role in detoxification and storage [21]-[23].

The level of $\mathrm{Cd}$ is at the level of the detection limit and whenever measurable are rather constant in all the analyses tissues. Renal dysfunction has been linked to Cd concentration in liver exceeding $20 \mu \mathrm{g} / \mathrm{g}$ w. wet [24].

The detectable levels of Cd (0.31 - $0.45 \mu \mathrm{g} / \mathrm{g}$ wet weight) in levels indicating a diet predominant in fish [25], according to the works of Boutiba (1992) [15] the food régime of $D$. delphis of the Algerian coasts is composed of fish and cephalopods who appear in, respectively, to the rate of $93.56 \%$ and $6.44 \%$ in the stomachs of this species. But cephalopods are known to contain for higher levels of metals than fish [26]. 
Table 3. Trace element levels (Mean $\pm \mathrm{SE} ; \mu \mathrm{g} / \mathrm{g}$ w.wt.) in the muscle, the blubber and the liver of Delphinus delphis:(M: Muscle; B: Blubber; L: Liver).

\begin{tabular}{|c|c|c|c|c|c|c|}
\hline Tissus & $\mathrm{Cu}$ & $\mathrm{Fe}$ & $\mathrm{Cd}$ & $\mathrm{Pb}$ & $\mathrm{Zn}$ & $\mathrm{Ni}$ \\
\hline $\mathrm{M}\left(\mathrm{N}^{\circ} 01\right)$ & $0.79 \pm 0.07$ & $143.97 \pm 2.82$ & $0.39 \pm 0.04$ & $3.74 \pm 1.19$ & $18.53 \pm 0.73$ & $45.97 \pm 7.59$ \\
\hline B & $0.07 \pm 0.01$ & $36.92 \pm 3.44$ & $0.21 \pm 0.10$ & $3.88 \pm 1.27$ & $20.72 \pm 0.77$ & $52.59 \pm 5.58$ \\
\hline $\mathrm{L}$ & $10.13 \pm 0.07$ & $165.36 \pm 3.27$ & $0.45 \pm 0.06$ & $4.12 \pm 1.37$ & $70.35 \pm 6.32$ & $53.29 \pm 2.90$ \\
\hline $\mathrm{M}\left(\mathrm{N}^{\circ} 02\right)$ & $0.50 \pm 0.06$ & $92.07 \pm 2.69$ & $0.25 \pm 0.03$ & $3.76 \pm 0.57$ & $15.03 \pm 2.26$ & $50.88 \pm 5.17$ \\
\hline B & $0.11 \pm 0.05$ & $41.91 \pm 4.57$ & $0.32 \pm 0.07$ & $4.47 \pm 0.35$ & $14.96 \pm 2.11$ & $43.40 \pm 6.54$ \\
\hline $\mathrm{L}$ & $4.75 \pm 0.73$ & $121.33 \pm 23.53$ & $0.30 \pm 0.03$ & $5.32 \pm 0.12$ & $48.80 \pm 5.42$ & $48.74 \pm 4.95$ \\
\hline $\mathrm{M}\left(\mathrm{N}^{\circ} 03\right)$ & $1.10 \pm 0.06$ & $64.71 \pm 1.59$ & $0.30 \pm 0.05$ & $4.77 \pm 1.34$ & $8.07 \pm 0.30$ & $52.14 \pm 1.77$ \\
\hline B & $0.06 \pm 0.02$ & $33.53 \pm 1.73$ & $0.33 \pm 0.04$ & $6.62 \pm 2.11$ & $7.95 \pm 0.39$ & $53.50 \pm 2.30$ \\
\hline $\mathrm{L}$ & $7.33 \pm 0.80$ & $149.85 \pm 2.42$ & $0.32 \pm 0.05$ & $4.17 \pm 0.24$ & $54.63 \pm 1.59$ & $55.38 \pm 2.67$ \\
\hline $\mathrm{M}\left(\mathrm{N}^{\circ} 04\right)$ & $0.69 \pm 0.07$ & $73.44 \pm 6.33$ & $0.33 \pm 0.02$ & $1.48 \pm 0.18$ & $27.51 \pm 1.89$ & $50.15 \pm 4.80$ \\
\hline B & $0.35 \pm 0.02$ & $49.24 \pm 3.82$ & $0.29 \pm 0.04$ & $1.02 \pm 0.40$ & $25.60 \pm 2.14$ & $48.47 \pm 3.69$ \\
\hline $\mathrm{L}$ & $13.50 \pm 0.20$ & $142.05 \pm 5.21$ & $0.34 \pm 0.04$ & $1.68 \pm 0.05$ & $29.79 \pm 3.68$ & $50.63 \pm 5.60$ \\
\hline $\mathrm{M}\left(\mathrm{N}^{\circ} 05\right)$ & $9.96 \pm 0.55$ & $140.45 \pm 14.76$ & $0.23 \pm 0.02$ & $0.64 \pm 0.26$ & $17.56 \pm 1.69$ & $46.62 \pm 7.26$ \\
\hline B & $4.82 \pm 1.34$ & $36.58 \pm 7.54$ & $0.23 \pm 0.02$ & $0.45 \pm 0.13$ & $12.62 \pm 2.94$ & $46.08 \pm 3.81$ \\
\hline $\mathrm{L}$ & $39.63 \pm 6.76$ & $123.16 \pm 2.54$ & $0.34 \pm 0.05$ & $1.95 \pm 1.03$ & $30.71 \pm 5.64$ & $44.66 \pm 4.70$ \\
\hline $\mathrm{M}\left(\mathrm{N}^{\circ} 06\right)$ & $0.57 \pm 0.08$ & $81.03 \pm 9.74$ & $0.32 \pm 0.04$ & $0.94 \pm 0.29$ & $26.71 \pm 8.04$ & $42.46 \pm 7.36$ \\
\hline B & $0.07 \pm 0.01$ & $38.45 \pm 8.14$ & $0.31 \pm 0.04$ & $0.41 \pm 0.02$ & $23.45 \pm 2.20$ & $47.40 \pm 1.96$ \\
\hline $\mathrm{L}$ & $3.62 \pm 0.28$ & $132.63 \pm 3.03$ & $0.35 \pm 0.04$ & $0.57 \pm 0.19$ & $33.75 \pm 2.24$ & $49.88 \pm 3.37$ \\
\hline $\mathrm{M}\left(\mathrm{N}^{\circ} 07\right)$ & $0.63 \pm 0.11$ & $118.52 \pm 5.98$ & $0.30 \pm 0.03$ & $0.25 \pm 0.10$ & $23.59 \pm 2.65$ & $49.84 \pm 1.73$ \\
\hline B & $0.50 \pm 0.08$ & $75.36 \pm 2.82$ & $0.30 \pm 0.03$ & $0.21 \pm 0.01$ & $16.75 \pm 3.34$ & $52.44 \pm 3.35$ \\
\hline $\mathrm{L}$ & $0.48 \pm 0.08$ & $99.24 \pm 15.55$ & $0.31 \pm 0.04$ & $0.26 \pm 0.03$ & $23.48 \pm 2.35$ & $50.30 \pm 1.33$ \\
\hline
\end{tabular}

$\mathrm{Pb}$ liver levels were higher to other studies, except for three dolphins $\left(\mathrm{N}^{\circ}: 1 ; 2 ; 3\right)$ that showed a liver concentration a value for greater in dolphin $\left(\mathrm{N}^{\circ}: 3\right), \mathrm{Pb}$ concentrations in foetus were not correlated to Pb concentrations in their mother.

It has to be noted that values ranging from 0.38 to $7 \mu \mathrm{g} / \mathrm{gwet}$ weight in the liver of four bottlenose dolphins, one common dolphin and one striped dolphin from the Irish Sea have been reported [3] [21].

However, these values indicate that $\mathrm{Pb}$ concentrations in liver of these individuals are a lot of agreement with those gotten in the literature.

Even when only intraspecific variation is considered, $\mathrm{Pb}$ concentrations were highly variable among the same age class of this study, and no clear general pattern could be shown regarding to the geographical origin of stranding or the species.

Among factors affecting individual variation, diet is probably one of the most important, and most persistent contaminants are incorporated into the body of mammals via food [5].

Most of the studies dealing with $\mathrm{Pb}$ in marine mammals have been carried out on soft tissues, in which $\mathrm{Pb}$ concentrations are often very low (less than $1 \mu \mathrm{g} / \mathrm{gwet}$ weight) [27].

In order to assess pollutant transfer between parent and offspring, much higher Cu concentration has been reported in all tissues of mother dolphin.

In the present study, $\mathrm{Cu}$ concentrations in liver were lower than values previously published, and the significant differences of $\mathrm{Cu}$ were detected in pregnant females and for the foetus especially in liver, the particular higher levels encountered in the liver of foetus, points out an important transplacental transfer of this metal [28] [29].

Law et al. (1991) [21] suggested that it is possible to hypothesize a range of liver concentrations within which this regulation is active, for example, approximately 3 - $30 \mu \mathrm{g} / \mathrm{g}$ for $\mathrm{Cu}$.

Significantly higher $\mathrm{Cu}$ concentrations were found in pregnant female dolphins compared to non-pregnant female suggesting that $\mathrm{Cu}$ may be required for growth and development of the embryo [30].

Another study suggested that these higher $\mathrm{Cu}$ and $\mathrm{Zn}$ concentrations in juveniles might relate to a biochemical requirement in newborns or a very low excretion rate of these elements by the fetus [28].

Disruption of essential element homeostasis is a powerful mechanism of metal toxicity [31], but conversely, essential element status also regulates the toxicity of heavy metals, intensifying the health effects in times of 
essential element deficiency and affording some protections where micronutrient status is adequate [32].

Therefore, these elements are not likely to have significant toxicological impacts on the dolphin populations in this study.

The element measured at highest concentration in this study was the Nickel, were it was in the range of 42.46 - $55.38 \mu \mathrm{g} / \mathrm{g}$, for example, younger dolphins appear to have higher Ni level than pregnant mother.

In mammals generally, dietary nickel is poorly absorbed and relatively nontoxic [4], but we found an order of magnitude higher range of Ni concentrations $(2.36-47.8 \mathrm{mg} / \mathrm{kg})$ than the reported range of $0.05-0.49 \mathrm{mg} / \mathrm{kg}$ in striped dolphins sampled between 1977 and 1980 in Japan [4].

Nevertheless, apart from metal body burden data, only limited information is available, especially on the related health effects.

The metal accumulation is also influenced by age, length, weight, sex and the sea area where dolphins live [7] [33] [34], but in this work for the seven specimens examined, it has not been possible to establish a correlation between metal concentrations and length or sex, the number of specimens was rather small, and it is difficult to offer a conclusive statement that geographic location is a contributing factor to these element concentration differences in the tissues of Common dolphins.

Samples for trace measurements in cetaceans generally originate of stranding into single events, the chemical levels may not reflect sometimes those of healthy population since stranded Individuals could suffer from diseases or parasitism's and additionally exhibit a poor nutritional status [35].

\section{Conclusions}

The present study provides new information on trace element concentrations in the tissues of common dolphins (Delphinus delphis) stranded along the Algerian west coast.

Very high Ni concentrations in the tissues of these species, on the other hand, $\mathrm{Cu}, \mathrm{Fe}, \mathrm{Cd}, \mathrm{Zn}$ concentrations measured were generally lower than those reported elsewhere for blubber, muscle and liver tissues of Mediterranean dolphins.

Very high $\mathrm{Cu}, \mathrm{Fe}, \mathrm{Cd}, \mathrm{Zn}$ concentrations in the liver of these marine mammals were related to be the most important accumulating organ for these metals.

Interspecific differences in the bioaccumulation, highest $\mathrm{Cu}$ concentration in liver, remain questionable and should be related to the physiology of this species.

Through the comparison of these results with those of other authors, besides the potential sources of variations bound to age, the sex and the food habits of the dolphins, it is clear that the liver was always the main organ to accumulate, and it is about an excretory organ of several compounds, to know if absorbed or produced in the organism, what could explain the level raised of some element toxic.

However, it has been demonstrated in this work that the Ni and Cd don't follow this behavior.

\section{Acknowledgements}

We are very grateful to all the participants, Bouranane and H. Charef from laboratory of SONATRACH (GNL1), thanks to O. Rouane-Hacene for their helpful comment on this work. Thanks also to all volunteers who helped with the collection of species.

\section{References}

[1] Frodello, J.P., Romeo, M. and Viale, D. (2000) Distribution of Mercury in the Organs of Five Odontocetous Whale Species of the Mediterranean. Environmental Pollution, 108, 447-452. http://dx.doi.org/10.1016/S0269-7491(99)00221-3

[2] Viale, D. (1978) Evidence of Metal Pollution in Cetacea of the Western Mediterranean. Annales de l'Institut Oceanographique, 54, 5-16.

[3] Law, R.J., Jones, B.R., Baker, J.R., Kennedy, S., Milne, R. and Morris, R.J. (1992) Trace Metals in the Livers of Marine Mammals from the Welsh Coast and Irish Sea. Marine Pollution Bulletin, 24, 296-304. http://dx.doi.org/10.1016/0025-326X(92)90590-3

[4] Law, R.J. (1996) Metals in Marine Mammals. In: Beyer, W.N., Heinz, G.H. and Redmon-Norwood, A.W., Eds., Environmental Contaminants in Wildlife. Interpreting Tissue Concentrations, SETAC Special Publication Series, Lewis Publishers Inc/CRC, Boca Raton, 357-365. 
[5] Aguilar, A., Borrel, A. and Pastor, T. (1999) Biological Factors Affecting Variability of Persistent Pollutant Levels in Cetaceans. In: Reijnders, P., Aguilar, A. and Donovan, G., Eds., Chemical Pollutants and Cetaceans. Journal of Cetacean Research and Management, Special Issue 1, UK, 83-116.

[6] Bilandzic, N., Sedak, M., Đokić, M., Đuras Gomerčić, M., Gomerčić, T., Zadravec, M., Benić, M. and Prevendar Crnić, A. (2012) Toxic Element Concentrations in the Bottlenose (Tursiops truncatus), Striped (Stenella coeruleoalba) and Risso's (Grampus griseus) Dolphins Stranded in Eastern Adriatic Sea. Bulletin of Environmental Contamination and Toxicology, 89, 467-473. http://dx.doi.org/10.1007/s00128-012-0716-6

[7] Andre, J.M., Boudou, A., Ribeyre, F. and Bernhard, M. (1991) Comparative Study of Mercury Accumulation in Dolphins (Stenella coeruleoalba) from French Atlantic and Mediterranean Coasts. Science of the Total Environment, 104, 191-209. http://dx.doi.org/10.1016/0048-9697(91)90072-M

[8] Tanabe, S. (2002) Contamination and Toxic Effects of Persistent Endocrine Disrupters in Marine Mammals and Birds. Marine Pollution Bulletin, 45, 69-77. http://dx.doi.org/10.1016/S0025-326X(02)00175-3

[9] Wafo, E., Sarazin, L., Diana, C., Dhermain, F., Schembri, T., Lagadec, V., Pecchia, M. and Rebouillon, P. (2005) Accumulation and Distribution of Organochlorines (PCBs and DDTs) in Various Organs of Stenella coeruleoalba and a Tursiops truncatus from Mediterranean Littoral Environment (France). Science of The Total Environment, 348, 115127. http://dx.doi.org/10.1016/j.scitotenv.2004.12.078

[10] Borrell, A. and Aguilar, A. (2007) Organochlorine Concentrations Declined during 1987-2002 in Western Mediterranean Bottlenose Dolphins, a Coastal Top Predator. Chemosphere, 66, 347-352. http://dx.doi.org/10.1016/j.chemosphere.2006.04.074

[11] Taleb, M.Z. and Boutiba, Z. (1999) The Organochlorine Compounds: Threat to the Cetaceans of the Algerian Waters. Proceedings of the 13th Annual ECS Conference, Valencia, 5-8 April1999, 25-30.

[12] Boutiba, Z., Taleb, M.Z. and Abi Ayad, S.M. El A. (2003)Etat de la pollution marine de la côte oranaise. Dar El Gharb, Oran, 69p.

[13] Bouragba-Benazza, M., Taleb, M.Z. and Boutiba, Z. (2006) Impacts des eaux usées de l'agglomération oranaise et des embouchures de Oued Cheliff et de Oued Tafna sur l'écosystème marin côtier occidental algérien. Workshop International surla Gestion Intégrée des Zones Côtières (GIZC): Problèmes et perspectives, 11-13 Décembre 2006, ISMAL, Alger.

[14] Jauniaux, T., Garcia-Hartmann, M., Haelters, J., Tavernier, J. and Coignoul, F. (2002) Echouage de mammifères marins: Guide d'intervention et procédure d'autopsie. Annales de Médecine Vétérinaire, 146, 261-276.

[15] Boutiba, Z. (1992) Les mammifères marins d’Algérie statut, Répartition, Biologie et Ecologie. Thèse Doctorat d’Etat, Université d’Oran, Algérie, 512p.

[16] Nooris, K. (1961) Standardized Methods for Measuring and Recording Data on the Smaller Cetaceans. Journal of Mammology, 42, 471-476. http://dx.doi.org/10.2307/1377364

[17] Amiard, J.C., Amiard-Triquet, J.C. and Metayer, C. (1987) Application de la Spéctrophotométrie d’Absorption Atomique Zeeman au dosage de 8 éléments traces ( $\mathrm{Hg}, \mathrm{Cd}, \mathrm{Cr}, \mathrm{Mn}, \mathrm{Ni}, \mathrm{Pb}, \mathrm{Se}$ ) dans les matières biologiques solides. Water Research, 21, 693-697. http://dx.doi.org/10.1016/0043-1354(87)90081-9

[18] Shoham-Frider, E., Kress, N., Wynne, D., Scheinin, A., Roditi-Elsar, M. and Kerem, D. (2009) Persistent Organochlorine Pollutants and Heavy Metals in Tissues of Common Bottlenose Dolphin (Tursiops truncatus) from the Levantine Basin of the Eastern Mediterranean. Chemosphere, 77, 621-627. http://dx.doi.org/10.1016/j.chemosphere.2009.08.048

[19] Lahaye, V., Bustamante, P., Dabin, W., Churlaud, C. and Caurant, F. (2007) Trace Element Levels in Foetus-Mother Pairs of Short-Beaked Common Dolphins (Delphinusdelphis) Stranded along the French Coasts. Environment International, 33, 1021-1028. http://dx.doi.org/10.1016/j.envint.2007.05.008

[20] Carvalho, M.L., Pereira, R.A. and Brito, J. (2002) Heavy Metals in Soft Tissues of Tursiops truncatus and Delphinus delphis from West Atlantic Ocean by X-Ray Spectrometry. Science of the Total Environment, 292, 247-254. http://dx.doi.org/10.1016/S0048-9697(01)01131-7

[21] Law, R.J., Fileman, C.F., Hopkins, A.D., Baker, J.R., Harwood, J., Jackson, D.B., Kennedy, S., Martin, A.R. and Morris, R.J. (1991) Concentrations of Trace Metals in the Livers of Marine Mammals (Seals, Porpoises and Dolphins) from Waters around the British Isles. Marine Pollution Bulletin, 22, 183-191. http://dx.doi.org/10.1016/0025-326X(91)90468-8

[22] Augier, H., Park, W.K. and Ronneau, C. (1993) Mercury Contamination of the Striped Dolphin Stenella coreruleoalba Meyen from the French Mediterranean Coasts. Marine Pollution Bulletin, 26, 301-311. http://dx.doi.org/10.1016/0025-326X(93)90572-2

[23] Bustamante, P., Cosson, R.P., Gallien, I., Caurant, F. and Miramand, P. (2002) Cadmium Detoxification Processes in the Digestive Gland of Cephalopods in Relation to Accumulated Cadmium Concentrations. Marine Environmental 
Research, 53, 227-241. http://dx.doi.org/10.1016/S0141-1136(01)00108-8

[24] Honda, K. (1985) Kaisan-honyurui no jfikinzoku no seibutsu n6shuku ni kansuru kenkyfi (Study on Bioaccumulations of Heavy Metals in Marine Mammals). Ph.D. Thesis, University of Tokyo, Tokyo, 101p.

[25] Law, R.J., Morris, R.J., Allchin, C.R., Jones, B.R. and Nicholson, M.D. (2003) Metals and Organochlorines in Small Cetaceans Stranded on the East Coast of Australia. Marine Pollution Bulletin, 46, 1206-1211. http://dx.doi.org/10.1016/S0025-326X(03)00220-0

[26] Long, M., Reid, R.J. and Kemper, C.M. (1997) Cadmium Accumulation and Toxicity in the Bottlenose Dolphin, the Common Dolphin, and Some Dolphin Prey Species in South Australia. Australian Mammology, 20, 25-33.

[27] Cardellicchio, N., Decataldo, A., Di Leo, A. and Giandomenico, S. (2002) Trace Elements in Organs and Tissues of Striped Dolphins (Stenella coeruleoalba) from the Mediterranean Sea (Southern Italy). Chemosphere, 49, 85-90. http://dx.doi.org/10.1016/S0045-6535(02)00170-4

[28] Wagemann, R., Stewart, R.E.A., Lockhart, W.L., Stewart, B.E. and Povoledo, M. (1988) Trace Metals and Methyl Mercury: Associations and Transfer in Harp Seal (Phoca groenlandica) Mothers and Their Pups. Marine Mammal Science, 4, 339-355. http://dx.doi.org/10.1111/j.1748-7692.1988.tb00542.x

[29] Yang, J., Kunito, T., Anan, Y., Tanabe, S. and Miyasaki, N. (2004) Total and Subcellular Distribution of Trace Elements in the Liver of a Mother-Fetus of Dall's Porpoises (Phocoenoides dalli). Marine Pollution Bulletin, 48, 11221129. http://dx.doi.org/10.1016/j.marpolbul.2003.12.019

[30] Eisler, R. (1998) Nickel Hazards to Fish, Wildlife and Invertebrates: A Synoptic Review. Biological Science Report USGS/BRD/BSR-1998-0001, Biological Resources Division, U.S. Geological Survey, Reston, 76p.

[31] Lopez Alonso, M., Benedito, J.L., Miranda, M., Castillo, C., Hernandez, J. and Shore, R.F. (2002) Interactions between Toxic and Essential Trace Metals in Cattle from a Region with Low Levels of Pollution. Archives of Environmental Contamination and Toxicology, 42, 165-172. http://dx.doi.org/10.1007/s00244-001-0012-7

[32] Peraza, M.A., Ayala-Fierro, F., Barber, D.S., Casarez, E. and Rael, L.T. (1998) Effects of Micronutrients on Metal Toxicity. Environmental Health Perspectives, 106, 203-216.

[33] Itano, K., Kawai, S., Miyazaki, N., Tatsukawa, R. and Fujiyama, T. (1984) Body Burdens and Distribution of Mercury and Selenium in Striped Dolphins. Agriculture and Biological Chemistry, 48, 1117-1121.

[34] Andre, J.M., Ribeyre, F. and Boudou, A. (1990) Mercury Contamination Levels and Distribution in Tissues and Organs of Delphinids (Stenella attenuata) from the Eastern Tropical Pacific, in Relation to Biological and Ecological Factors. Marine Environmental Research, 30, 43-72. http://dx.doi.org/10.1016/0141-1136(90)90010-L

[35] Dehn, L.A., Sheffield, G.G., Follmann, E.H., Duffy, L.K., Thomas, D.L., Bratton, G.R., Taylor, R.J. and O’Hara, T.M. (2005) Trace Elements in Tissues of Phocids Seals Harvested in the Alaska and Canadian Arctic: Influence of Age and Feeding Ecology. Canadian Journal of Zoology, 83, 726-746. http://dx.doi.org/10.1139/z05-053 